\title{
Impacts of Integrated Farming System on Socio-economics and Livelihood Sustainability of Small and Marginal Farmers in Chhattisgarh
}

\author{
Anil Kumar Netam ${ }^{*}$, Birbal Sahu ${ }^{2}$ and Chainu Ram Netam ${ }^{3}$
}

\author{
${ }^{1}$ AICRP on IFS - On Farm Research, IGKV, Krishi Vigyan Kendra, Kanker, \\ Chhattisgarh, India \\ ${ }^{2}$ Krishi Vigyan Kendra, Kanker, Chhattisgarh, India \\ ${ }^{3}$ College of Agriculture \& Research Station, Bemetara, Chhattisgarh, India
}

*Corresponding author

\section{Keywords}

Integrated farming system, Production, Socio-economics, Livelihood, employment, Resource recycling

Article Info

Accepted: 07 March 2019 Available Online: 10 April 2019

\section{A B S T R A C T}

The integrated farming system study was conducted at farmers field of village -Mohpur, BlockKanker, District- Uttar Bastar Kanker (C.G.) under All India Coordinated Research Project on Integrated Farming System- On Farm Research, Indira Gandhi Krishi Vishwavidyalaya, Krishi Vigyan Kendra, Kanker during July, 2017- June, 2018 for finding the contribution of total income to the livelihood of farmers who practices integrated farming system. Study was conducted in crop + vegetable + dairy + Goatry + piggery + poultry + duck + fisheries + lac cultivation + minor forest produce + FYM \& vermi-compost + Azolla production farming system in 1.0 hectare area under irrigated condition. Out of one hectare area, 0.606 ha was allotted for crop component i.e field crops (rice, blackgram, pigeon pea, sweet corn) \& vegetables (tomato, brinjal, onion, potato, peas, chilly, cucubits etc), 0.2 ha for lac cultivation, 0.13 ha for fisheries, 0.006 ha for organic manure production, 0.03 ha for animal husbandry \& poultry and 0.03 ha for residency \& other. Growing field crops and vegetables with 60 percent area in order to meet the family food requirement and in addition to get better profit out of these produce. The results of one year study of integrated farming system indicated that the economic yield was $244.69 \mathrm{q}$ with the highest been contributed by vegetables $(116.52 \mathrm{q})$, followed by organic manure (87.65 q), field crops (30.80), animal husbandry (2.85 q), minor forest produce (2.80 q), Azolla production (1.44 q), lac cultivation (1.40 q), fisheries $(0.70 \mathrm{q})$ and poultry (0.53 q). Similarly annual total net return of the IFS model was Rs. 217591.00 with the highest been contributed by vegetables (Rs. 101860), followed by field crops (Rs. 34067), organic manure production (Rs. 24130), lac cultivation (Rs. 17440), animal husbandry (Rs. 17010), poultry (Rs. 14530) minor forest produce (Rs. 5630), fisheries (Rs.4700) and Azolla (Rs. 1584). Effective recycling of farm by products and waste in terms of FYM (46.4 q), vermicompost (32 q), goat manure (7.6 q) and poultry manure (1.65 q) and can save Rs. 30150.00 per year. The total annual mandays generated for family members by IFS model was 619 and highest been contributed by vegetable production (265 mandays) followed by animal husbandry (108 mandays). Thus, we can conclude that adoption of integrated farming systems improves the profitability and achieve sustainable production by effective recycling of natural resource in addition to meeting family needs. 


\section{Introduction}

Agriculture has always been considered as the back- bone of our country. In India $70 \%$ of rural population is engaged in agriculture and $80 \%$ of population live, directly or indirectly on income delivered from agriculture. There are 115 million operational holdings in the country and about $80 \%$ are marginal and small farmers (Manjunatha et al., 2014). To fulfill the basic needs of house hold including food (cereal, pulses, oilseeds, milk, fruit, honey, meat, etc.), feed, fodder, fiber, etc. warrant an attention about Integrated Farming System. Undoubtedly, majority of the farmers are doing farming since long back but their main focus was individual components but not in a integrated manner. At the ICAR and State Agricultural Universities level, lot of efforts have been made aiming at increasing the productivity of different components of farming system i.e. crops, horticultural crops, live stock (dairy, goatry, piggery), poultry (chicken, ducks, quail, pigeons), lac cultivation, apiculture, sericulture, mushroom cultivation, organic manures production, biogas etc. individually but lacking in their integration by following farming system approach. The integration is made in such a way that product of one component should be the input for other enterprises with high degree of complimentary effects on each other.

The operational farm holding in India is declining and over 85 million out of 115 million are below the size of 1 ha (Manjunatha et al., 2014). Due to ever increasing population and decline in per capita availability of land in the country, practically there is no scope for horizontal expansion of land for agriculture. Only vertical expansion is possible by integrating farming components requiring lesser space and time and ensuring reasonable returns to farm families. The Integrated Farming System therefore assumes greater importance for sound management of farm resources to enhance the farm productivity and reduce the environmental degradation, improve the quality of life of resource poor farmers and maintain sustainability. In order to sustain a positive growth rate in agriculture, a holistic approach is the need of the hour. Farming system is a mix of farm enterprises in which farm families allocate resources for efficient utilization of the existing enterprises for enhancing productivity and profitability of the farm (Varughese et al., 2009). Integrated farming system approach is not only a reliable way of obtaining fairly high productivity with considerable scope for resource recycling, but also concept of ecological soundness leading to sustainable agriculture. One of the option to evaluate the potential of age- old mixed farming now as a IFS in enhancing income of farm families within the reasonable time period.

\section{Materials and Methods}

The integrated farming system study was conducted at farmers field of village Mohpur, Block- Kanker, District- Uttar Bastar Kanker (C.G.) under All India Coordinated Research Project on Integrated Farming System- On Farm Research, Indira Gandhi Krishi Vishwavidyalaya, Krishi Vigyan Kendra, Kanker during July, 2017- June, 2018 for finding the contribution of total income to the livelihood of farmers who practices integrated farming system. Study was conducted in field crops + vegetable + dairy + Goatry + piggery + poultry + duck + fisheries + lac cultivation + minor forest produce + FYM \& vermi-compost + Azolla production farming system in 1.0 hectare area under irrigated condition. Topography of soil was upland and midland with sandy loam soil. Out of one hectare area, 0.606 ha was allotted for crop component i.e. field crops (rice, blackgram, pigeon pea, sweet corn) \& 
vegetables (tomato, brinjal, onion, potato, peas, chilly, cucubits etc), 0.2 ha was taken for lac cultivation, 0.13 ha for fisheries, 0.006 ha for organic manure production, 0.03 ha animal \& poultry and 0.03 ha for residency. Total gross cropped area was 1.51 ha wherein under vegetables (0.91 ha) and field crops (0.6 ha). Technical and some physical inputs of agriculture are given to farmer during the study period. All the activities regarding farming i.e. crops cultivation, livestock rearing, poultry, fish culture, lac cultivation, organic manures and Azolla production, minor forest produce collection, homestead components and spent time of family members recorded every day in data register by household members and the data were also recorded personally by the researcher by visiting the study area and interviewing the family members. All possible efforts were made to ensure the collection of reasonably accurate data from the farm household through face- to- face interview and recall basis.

Cost of cultivation of every farm enterprises calculated by sum of internal input cost, external input cost, labour cost and transportation cost. Gross returns from farm produce calculate on the basis of total produce and sold produce of farm enterprises separately. Also recorded the by products of every enterprises of farm and their recycling pattern within a farm and outside of farm. Forest trees are also in existing farming system; therefore data relevant to minor forest produce collection and income generation also recorded.

\section{Results and Discussion}

\section{Economics of integrated farming system}

The data after study indicated that adoption of integrated farming system by inclusion of crops based enterprises, animal husbandry (dairy, goatry, piggery), poultry (back yard poultry, ducks, pigeons), fisheries, lac cultivation, minor forest produce and organic manures production recorded annual total gross return of the IFS model was Rs. 347103.00 (Table 5) with the highest been contributed by vegetables (Rs. 165540), followed by field crops (Rs. 55199), organic manure production (Rs. 30150), animal husbandry (Rs. 28550), lac cultivation (Rs. 25200), poultry (Rs. 19210), minor forest produce (Rs. 10430), fisheries (Rs. 9800) and Azolla production (Rs. 3024). Integration of farm enterprises generated additional gross income Rs. 126364.00 per annum where in comparison to Rs. 220739.00 by field and vegetable crops.

Annual total net return of the IFS model was Rs. 217591.00 with the highest been contributed by vegetables (Rs. 101860), followed by field crops (Rs. 34067), organic manure production (Rs. 24130), lac cultivation (Rs. 17440), animal husbandry (Rs. 17010), poultry (Rs. 14530), minor forest produce (Rs. 5630), fisheries (Rs.4700) and Azolla (Rs. 1584). Integration of different farm enterprises generated additional net income Rs. 81664.00 per annum where in comparison to Rs. 135927.00 by field and vegetable crops. Average B: $\mathrm{C}$ ratio of the farming system was 2.69 and highest was under organic manure production (5.01) followed by poultry (4.10), lac cultivation (3.25), field crops production (2.61), vegetables production (2.60), minor forest produce (2.17), Azolla production (2.10), animal husbandry (1.96) and fisheries (1.92). Kumara et al., (2017) also found that inclusion of enterprises in integrated farming system in 1 ha area gave average net returns of Rs. 186571.00 per annum with the highest been contributed by dairy (Rs. 47378), horticulture (Rs. 38526), and sheep (Rs. 17876). In Tamilnadu Jayanti et al., (2001) found that the net return of IFS (Cropping + 
fish + poultry) was on an average of Rs. 97731/ha/year over the arable farming (Rs 36190/ha/year). While in Goa Manjunath et al., (2003) recorded that the net return of IFS (Rice-Brinjal (0.5 ha) + Rice- cowpea (0.5 ha) + mushroom + poultry) was Rs. 75360.00 per year over the cashew nut cultivation (Rs. 36330) alone. In Madhya Pradesh Tiwari et al., (1999) found that the integrated farming gave a margin in net return of Rs 44913/ ha/year over the arable farming (Rs. 24093).

Annual total cost of cultivation of the IFS model was Rs. 129152.00 and highest was under vegetables production (Rs. 63680), followed by field crop production (Rs. 21132), animal husbandry (Rs. 14540), lac cultivation (Rs. 7760), organic manure production (Rs. 6020), fisheries (Rs. 5100), minor forest produce (Rs. 4800), poultry (Rs. 4680) and Azolla production (Rs. 1440). Integrated farming system (crop + dairy + horticultural + fishery + mushroom + apiary + vermicompost) study of 1.0 ha area conducted at western plain zone of Uttar Pradesh by Singh et al., and recorded that total cost of cultivation of IFS model was Rs. 267295.00 per year, gross return Rs. 570705.00 per year and net return 303410.00 per year. Annual total gross income of the IFS model on the basis of sold farm produce was Rs. 274489.00 with the highest been contributed by vegetables (Rs. 159265), followed by field crops (Rs. 37174), animal husbandry (Rs. 25650), lac cultivation (Rs. 25200), poultry (Rs. 11850), minor forest produce (8630) and fisheries (Rs.6720). Due to integration of enterprises with in a farm generated additional gross income Rs. 78050.00 per annum on the basis of sold produce as compare to Rs. 196439.00 by crops only. Annual total net income of the IFS model on the basis of sold produce was Rs. 153567.00 and highest was under vegetables production (Rs. 95585), followed by lac cultivation (Rs. 17440), field crop production (Rs. 16042), animal husbandry (Rs. 11110), poultry (Rs.
7170), minor forest produce (3830) and fisheries (Rs.1620). Integration of farm enterprises generated additional net income Rs. 33710.00 per annum where in comparison to Rs. 111627.00 by field and vegetable crops. In Haryana, Singh et al., (1993) conducted studies of various farming systems on 1 ha of irrigated and 1.5 ha of unirrigated land and found that under irrigated conditions of mixed farming with crossbred cows yielded the highest net profit (Rs 20,581/-) followed by mixed farming with buffaloes (Rs 6,218/-) and lowest in arable farming (Rs 4,615/-). Another study involving cropping, poultry, pigeon, goat and fishery was conducted under wetland conditions of Tamil Nadu conducted by Jayanthi et al., (2001) three years results revealed that integration of crop with fish (400 reared in 3 ponds of 0.04 ha each), poultry (20 babkok layer bird), pigeon (40 pairs), and goat (Tellichery breed of 20 female and 1 male in 0.03 ha deep litter system) resulted in higher productivity, higher economic return of Rs 1, 31,118 (mean of 3 year) (Table 2).

\section{Economic yield of enterprises in integrated farming system}

Annual total economic yield of IFS model was 244.69 q (Table 4) with the highest been contributed by vegetables $(116.52$ q), followed by organic manure $(87.65 \mathrm{q})$, field crops (30.80), animal husbandry (2.85 q), minor forest produce $(2.80 \mathrm{q})$, Azolla production $(1.44 \mathrm{q})$, lac cultivation $(1.40 \mathrm{q})$, fisheries $(0.70 \mathrm{q})$ and poultry $(0.53 \mathrm{q})$. Annual total family consumption of economic yield of IFS model was $15.75 \mathrm{q}$ and highest was under field crops $(10.85 \mathrm{q})$, followed by vegetables (4.04 q), minor forest produce $(0.60 \mathrm{q})$, animal husbandry produce $(0.44 \mathrm{q})$, fisheries $(0.22$ q) and poultry $(0.20$ q). Organic manures $87.65 \mathrm{q}$ used for crop production and Azolla $1.44 \mathrm{q}$ used for feeding to poultry \& pigs at own farm (Table 3 ). 
Table.1 Productivity of farm enterprises in integrated farming system model

\begin{tabular}{|c|c|c|c|c|c|c|c|c|c|c|c|c|c|c|c|}
\hline \multirow[t]{2}{*}{ Enterprises } & \multirow[t]{2}{*}{$\begin{array}{l}\text { Area } \\
\text { (ha) }\end{array}$} & \multirow[t]{2}{*}{$\begin{array}{l}\text { Economic } \\
\text { yield }(q)\end{array}$} & \multirow{2}{*}{$\begin{array}{c}\text { Family } \\
\text { consumption } \\
\text { (q) }\end{array}$} & \multirow[t]{2}{*}{$\begin{array}{l}\text { Sold } \\
(\mathbf{q})\end{array}$} & \multirow[t]{2}{*}{ Rs./ q } & \multirow{2}{*}{$\begin{array}{l}\text { Gross } \\
\text { return } \\
(\text { Rs. })\end{array}$} & \multirow{2}{*}{$\begin{array}{c}\text { Cost of } \\
\text { production } \\
\text { (Rs.) }\end{array}$} & \multirow{2}{*}{$\begin{array}{l}\text { Net } \\
\text { return } \\
\text { (Rs.) }\end{array}$} & \multirow[t]{2}{*}{$\begin{array}{l}\text { Straw } \\
\text { (q) }\end{array}$} & \multicolumn{2}{|c|}{ Use of residue } & \multirow{2}{*}{$\begin{array}{l}\text { Family } \\
\text { labour } \\
\text { (Man } \\
\text { days) }\end{array}$} & \multirow[t]{2}{*}{ B:C } & \multicolumn{2}{|c|}{$\begin{array}{l}\text { On sold farm } \\
\text { produce (Rs.) }\end{array}$} \\
\hline & & & & & & & & & & $\begin{array}{l}\text { Feed } \\
(\mathbf{q})\end{array}$ & $\begin{array}{l}\text { Composting } \\
\text { (q) }\end{array}$ & & & $\begin{array}{l}\text { Gross } \\
\text { return }\end{array}$ & $\begin{array}{l}\text { Net } \\
\text { return }\end{array}$ \\
\hline \multicolumn{16}{|l|}{ Field crops } \\
\hline Rice & 0.4 & 18.6 & 9.5 & 9.1 & 1590 & 29574 & 12140 & 17434 & 16.4 & 14.8 & 1.6 & 48 & 2.44 & 14469 & 2329 \\
\hline Blackgram & 0.1 & 1.05 & 0.3 & 0.75 & 4500 & 4725 & 2120 & 2605 & 1.47 & 0.5 & 0.97 & 13 & 2.23 & 3375 & 1255 \\
\hline Pigeon pea & 0 & 0.9 & 0.25 & 0.65 & 5000 & 4500 & 1480 & 3020 & 0.8 & 0 & 0.8 & 6 & 3.04 & 3250 & 1770 \\
\hline Sweet corn & 0.1 & 10.25 & 0.2 & 10.05 & 1600 & 16400 & 5392 & 11008 & 8 & 0 & 8 & 25 & 3.04 & 16080 & 10688 \\
\hline Total & 0.6 & 30.8 & 10.25 & 20.55 & $\mathbf{0}$ & 55199 & 21132 & 34067 & 26.67 & 15.3 & 11.37 & 92 & 2.61 & 37174 & 16042 \\
\hline \multicolumn{16}{|l|}{ Vegetables } \\
\hline Vegetables & 0.1 & 12.3 & 0.9 & 11.4 & 2000 & 24600 & 7800 & 16800 & 2.60 & 0 & 2.60 & 35 & 3.15 & 22800 & 15000 \\
\hline Vegetable. in Badi & 0.006 & 1.72 & 0.75 & 0.97 & 2000 & 3440 & 1260 & 2180 & 0.80 & 0 & 0.80 & 9 & 2.73 & 1940 & 680 \\
\hline Tomato & 0.2 & 28.2 & 0.32 & 27.88 & 1000 & 28200 & 13900 & 14300 & 2.45 & 0 & 2.45 & 59 & 2.03 & 27880 & 13980 \\
\hline Brinjal & 0.2 & 29 & 0.38 & 28.62 & 1000 & 29000 & 13600 & 15400 & 2.30 & 0 & 2.30 & 53 & 2.13 & 28620 & 15020 \\
\hline Onion \& potato & 0.1 & 14.1 & 0.55 & 13.55 & 1500 & 21150 & 7600 & 13550 & 0.85 & 0 & 0.85 & 27 & 2.78 & 20325 & 12725 \\
\hline Peas & 0.1 & 9.5 & 0.2 & 9.3 & 2500 & 23750 & 7400 & 16350 & 2.40 & 0 & 2.40 & 29 & 3.21 & 23250 & 15850 \\
\hline Chilly & 0.1 & 8.2 & 0.09 & 8.11 & 3000 & 24600 & 8200 & 16400 & 1.55 & 0 & 1.55 & 36 & 3.00 & 24330 & 16130 \\
\hline Cucurbits & 0.1 & 13.5 & 0.85 & 12.65 & 800 & 10800 & 3920 & 6880 & 1.80 & 0 & 1.80 & 17 & 2.76 & 10120 & 6200 \\
\hline Total & 0.906 & 116.52 & 4.04 & 112.48 & $\mathbf{0}$ & 165540 & 63680 & 101860 & 14.75 & $\mathbf{0}$ & 14.75 & 265 & 2.60 & 159265 & 95585 \\
\hline \multicolumn{16}{|l|}{ Animal husbandry } \\
\hline Cow & 8 & 2.2 & 0.4 & 1.8 & 4000 & 8800 & 7200 & 1600 & 0 & 0 & 46.40 & 60 & 1.22 & 7200 & 0 \\
\hline Goatry & 11 & 0.27 & 0.02 & 0.25 & 45000 & 12150 & 5400 & 6750 & 0 & 0 & 7.60 & 40 & 2.25 & 11250 & 5850 \\
\hline Pig & 3 & 0.38 & 0.02 & 0.36 & 20000 & 7600 & 1940 & 5660 & 0 & 0 & 0 & 8 & 3.92 & 7200 & 5260 \\
\hline Total & 22 & 2.85 & 0.44 & 2.41 & $\mathbf{0}$ & 28550 & 14540 & 14010 & $\mathbf{0}$ & $\mathbf{0}$ & 54.00 & 108 & 1.96 & 25650 & 11110 \\
\hline \multicolumn{16}{|l|}{ Poultry } \\
\hline Back yard poultry & 46 & 0.41 & 0.16 & 0.25 & 41000 & 16810 & 3940 & 12870 & 0 & 0 & 1.30 & 18 & 4.27 & 10250 & 6310 \\
\hline Duck & 15 & 0.12 & 0.4 & 0.08 & 20000 & 2400 & 740 & 1660 & 0 & 0 & 0.38 & 2 & 3.24 & 1600 & 860 \\
\hline Total & 61 & 0.53 & 0.20 & 0.33 & 0 & 19210 & 4680 & 14530 & 0 & 0 & 1.68 & 20 & 4.10 & 11850 & 7170 \\
\hline
\end{tabular}


Table.2 Production and recycling of organic manures in integrated farming system model

\begin{tabular}{|l|c|c|c|c|c|c|c|c|}
\hline Organic manures & $\begin{array}{c}\text { Area } \\
\left(\mathbf{m}^{2}\right)\end{array}$ & $\begin{array}{c}\text { Production } \\
(\mathbf{q})\end{array}$ & $\begin{array}{c}\text { Use in } \\
\text { farm }(\mathbf{q})\end{array}$ & $\begin{array}{c}\text { Gross } \\
\text { return } \\
(\mathbf{R s} .)\end{array}$ & $\begin{array}{c}\text { Cost of } \\
\text { production } \\
(\mathbf{R s .})\end{array}$ & $\begin{array}{c}\text { Net } \\
\text { return } \\
(\text { Rs. })\end{array}$ & $\begin{array}{c}\text { Family } \\
\text { (abour } \\
\text { (Man days) }\end{array}$ & B:C \\
\hline FYM & 40 & 46.4 & 46.4 & 3250 & 600 & 2650 & 6 & 5.42 \\
\hline Goat Manure & 8 & 7.6 & 7.6 & 1000 & 120 & 880 & 1 & 8.33 \\
\hline Poultry manure & 2 & 1.65 & 1.65 & 300 & 120 & 180 & 1 & 2.50 \\
\hline Vermi compost & 12 & 32 & 32 & 25600 & 5180 & 20420 & 39 & 4.94 \\
\hline Total & $\mathbf{6 2}$ & $\mathbf{8 7 . 6 5}$ & $\mathbf{8 7 . 6 5}$ & $\mathbf{3 0 1 5 0}$ & $\mathbf{6 0 2 0}$ & $\mathbf{2 4 1 3 0}$ & $\mathbf{4 7}$ & $\mathbf{5 . 0 1}$ \\
\hline
\end{tabular}

Table.3 Minor forest produces collection in integrated farming system model

\begin{tabular}{|l|c|c|c|c|c|c|c|c|}
\hline $\begin{array}{l}\text { Minor forest } \\
\text { produces }\end{array}$ & $\begin{array}{c}\text { Tree/ } \\
\text { plants } \\
\text { (Nos.) }\end{array}$ & Production & $\begin{array}{c}\text { Family } \\
\text { consumption }\end{array}$ & $\begin{array}{c}\text { Gross } \\
\text { return } \\
\text { (Rs.) }\end{array}$ & $\begin{array}{c}\text { Cost of } \\
\text { collection } \\
\text { (Rs.) }\end{array}$ & $\begin{array}{c}\text { Net } \\
\text { return } \\
\text { (Rs.) })\end{array}$ & $\begin{array}{c}\text { Family } \\
\text { labour } \\
\text { (Man days) }\end{array}$ & B:C \\
\hline Mahua & 3 & $2.40 \mathrm{q}$ & $0.60 \mathrm{q}$ & 7200 & 3600 & 3600 & 30 & 2.00 \\
\hline Chironji & 5 & $0.40 \mathrm{q}$ & 0 & 1200 & 480 & 720 & 3 & 2.50 \\
\hline Tendu Patta & 2910 & 1400 bundle & 0 & 2030 & 720 & 1310 & 6 & 2.82 \\
\hline Total & $\mathbf{2 9 1 8}$ & & $\mathbf{0 . 6 0}$ & $\mathbf{1 0 4 3 0}$ & $\mathbf{4 8 0 0}$ & $\mathbf{5 6 3 0}$ & $\mathbf{3 9}$ & $\mathbf{2 . 1 7}$ \\
\hline
\end{tabular}

Table.4 Farm production, utilization and recycling of produces in integrated farming system model

\begin{tabular}{|l|c|c|c|c|c|c|c|c|}
\hline Enterprises & $\begin{array}{c}\text { Area } \\
\text { (ha) }\end{array}$ & $\begin{array}{c}\text { Economic } \\
\text { yield (q) }\end{array}$ & $\begin{array}{c}\text { Family } \\
\text { consumption/ } \\
\text { use in farm } \\
\text { (q) }\end{array}$ & $\begin{array}{c}\text { Sold } \\
\text { produce } \\
(\mathbf{q})\end{array}$ & $\begin{array}{c}\text { Stra } \\
\mathbf{w} \\
\text { yield } \\
(\mathbf{q})\end{array}$ & $\begin{array}{c}\text { Broken } \\
\text { rice \& } \\
\text { husk/ } \\
\text { other }\end{array}$ & Feed & Composting \\
\hline Field crops & 0.606 & 30.80 & 10.85 & 20.55 & 26.67 & 3.26 & $\begin{array}{c}18.5 \\
\text { Comp }\end{array}$ & 11.37 \\
\hline Vegetables & & 116.52 & 4.04 & 112.48 & 14.75 & 0 & 0 & 14.75 \\
\hline $\begin{array}{l}\text { Animal } \\
\text { husbandry }\end{array}$ & 0.028 & 2.85 & 0.44 & 2.41 & 0 & 0 & 0 & 54.00 \\
\hline Poultry & 0.002 & 0.53 & 0.20 & 0.33 & 0 & 0 & 0 & 1.68 \\
\hline Fisheries & 0.13 & 0.70 & 0.22 & 0.48 & 0 & 0 & 0 & 0 \\
\hline $\begin{array}{l}\text { Lac } \\
\text { cultivation }\end{array}$ & 0.20 & 1.40 & 0 & 1.40 & 7.80 & 0 & 0 & 7.80 \\
\hline $\begin{array}{l}\text { Organic } \\
\text { manures }\end{array}$ & 0.006 & 87.65 & 87.65 & 0 & - & 0 & - & - \\
\hline Azolla & 0.001 & 1.44 & 1.44 & 0 & - & 0 & - & - \\
\hline $\begin{array}{l}\text { Minor forest } \\
\text { produce }\end{array}$ & $0 \mathrm{n}$ & 2.80 & 0.60 & 2.20 & 0 & 0.60 & 0.60 & 0 \\
\hline \multicolumn{1}{c}{ Total } & $\mathbf{0 . 9 7}$ & $\mathbf{2 4 4 . 6 9}$ & $\mathbf{1 0 4 . 8 4}$ & $\mathbf{1 3 9 . 8 5}$ & $\mathbf{4 9 . 2 2}$ & $\mathbf{3 . 8 6}$ & $\mathbf{1 9 . 1}$ & $\mathbf{8 9 . 6 0}$ \\
\hline
\end{tabular}


Table.5 Economics and employment generation in integrated farming system model

\begin{tabular}{|c|c|c|c|c|c|c|c|}
\hline \multirow[t]{2}{*}{ Enterprises } & \multirow{2}{*}{$\begin{array}{c}\text { Cost of } \\
\text { production } \\
\text { (Rs.) }\end{array}$} & \multirow{2}{*}{$\begin{array}{l}\text { Gross } \\
\text { return } \\
\text { (Rs.) }\end{array}$} & \multirow{2}{*}{$\begin{array}{c}\text { Net } \\
\text { return } \\
\text { (Rs.) }\end{array}$} & \multirow{2}{*}{$\begin{array}{l}\text { B: } \mathrm{C} \\
\text { ratio }\end{array}$} & \multicolumn{2}{|c|}{ On sold farm produce } & \multirow{2}{*}{$\begin{array}{l}\text { Family labour } \\
\text { (mandays) }\end{array}$} \\
\hline & & & & & $\begin{array}{c}\text { Gross return } \\
\text { (Rs.) }\end{array}$ & $\begin{array}{l}\text { Net return } \\
\text { (Rs.) }\end{array}$ & \\
\hline Field crops & 21132 & 55199 & 34067 & 2.61 & 37174 & 16042 & 92 \\
\hline Vegetables & 63680 & 165540 & 101860 & 2.60 & 159265 & 95585 & 265 \\
\hline Animal husbandry & 14540 & 28550 & 14010 & 1.96 & 25650 & 11110 & 108 \\
\hline Poultry & 4680 & 19210 & 14530 & 4.10 & 11850 & 7170 & 20 \\
\hline Fisheries & 5100 & 9800 & 4700 & 1.92 & 6720 & 1620 & 12 \\
\hline Lac cultivation & 7760 & 25200 & 17440 & 3.25 & 25200 & 17440 & 24 \\
\hline Organic manures & 6020 & 30150 & 24130 & 5.01 & 0 & -6020 & 47 \\
\hline Azolla & 1440 & 3024 & 1584 & 2.10 & 0 & -1440 & 12 \\
\hline $\begin{array}{ll}\text { Minor } & \text { forest } \\
\text { produce } & \end{array}$ & 4800 & 10430 & 5630 & 2.17 & 8630 & 3830 & 39 \\
\hline Total & 129152 & 347103 & 217591 & 2.69 & 274489 & 145337 & 619 \\
\hline
\end{tabular}

Resource recycling in integrated farming system

Annual total straw yield of IFS model was 49.22 q (Table 2) with the highest been contributed by field crops $(26.67 \mathrm{q})$, followed by vegetables (14.75) and lac cultivation (7.80 q). Paddy straw 15.30 q used for feeding to animals and rest of the farm residues (33.92 q) utilized for compost production. Cow dung $(46.4 \mathrm{q})$, goat vista $(7.6 \mathrm{q})$ and poultry vista $(1.68 \mathrm{q})$ of farm used for FYM, goat and poultry manure production respectively. Total organic manures production was $87.65 \mathrm{q}$ with the highest been contributed by FYM (46.4 q) followed by vermicompost (32 q), goat manure $(7.6 \mathrm{q})$ and poultry manure $(1.65 \mathrm{q})$ and the total quantity $(87.65 \mathrm{q})$ of organic sources of nutrients are being recycled from farm waste obtained from different components. Recycling of farm wastes in form of organic manures within the system itself was found very economical in saving Rs. 30150.00 per year as well as save the use of chemical fertilizers or its substitutes and also improve the soil health condition, there by enhanced the organic matter and microbial activity which resulted in sustainable production. Similar findings also recorded by Kumara et al., (2017) that the total quantity $(462.50 \mathrm{~kg})$ of organic source of nutrients are being recycled from farm waste obtained from different components. More than 35 per cent of NPK requirement would be met through recycling of farm wastes in form of compost and vermi compost within the system itself. $1.44 \mathrm{q}$ of Azolla produced in farm was utilized as supplement feed for poultry and pigs

Employment generation in integrated farming system

Integrated farming system has created more number of working hours in the system due to involvement of more enterprises than cropping system alone. Total employment generation of IFS model for family members was 619 mandays per annum (Table 5) with the highest been contributed by vegetable production (265 mandays) followed by animal husbandry (108 mandays), field crop production (92 mandays), organic manures production (47 mandays), minor forest produce (39 mandays), lac cultivation (24 mandays), fisheries (12 mandays) and Azolla 
production (12 mandays). Integration of enterprises created the additional employment opportunity i.e. 262 mandays per annum as compare to only 357 mandays/ annum by cropping system alone. This has provided employment opportunity throughout the year due to involvement of more than one enterprise in the system. Kumara et al.,(2017) reported that 1.0 ha model has generated 515 mandays, 760 mandays, 1070 mandays and 932 mandays per hectare per year during 2012-13, 2013-14, 2014-15, 2015-16, respectively. Jayanthi et al., also found that integration of enterprises created the employment opportunities where in comparison to 369 mandays/year generated in cropping alone system, cropping with fish and goat created additional 207 man days/annum.

\section{References}

Jayanthi C, Rangasamy A, Mythili S, Balusamy M, Chinnusamy C, Sankaran N. 2001. Sustainable productivity and profitability to integrated farming systems in low land farms. In: Extended summaries, pp. 79-81. (Eds: A.K. Singh, B. Gangwar, Pankaj and P.S. Pandey), National Symposium on Farming System Research on New Millennium, PDCSR, Modipuram.

Kumara O., Sannathimmappa H.G., Basavarajappa, D.N., Danaraddi Vijay S., Pasha Akmal, Rajani, S.R. 2017. Integrated Farming System - An approach towards livelihood security, resource conservation and sustainable production for small and marginal farmers. International Journal of Plant \& Soil Science 15 (3): 1-9

Manjunath BL, Itnal CJ.2003. Farming system options for small and marginal holdings in different topographies of Goa. Indian J Agron. 48 (1): 4-8.

Manjunatha S.B., Shivmurthy D., Sunil A Satyareddi, Nagaraj M.V., Basavesha K.N. 2014. Integrated Farming System An Holistic Approach: A Review. Research and Reviews: Journal of Agriculture and Allied Sciences. 4(3): 30-38.

Singh CB, Renkema JA, Dhaka JP, Singh, Keran, Schiere, J.B. 1993. Income and employment on small farmers. In : Proceeding An International workshop on Feeding of Ruminants on fibrous crop residues: Aspects of treatment, feeding, nutrient evaluation, research and extension. Karnal, Haryana, 4-8 February, 1991, pp. 67-76.

Tiwari SP, Ravi R, Nandeha KL, Vardia HK, Sharma RB, and Rajgopal S. 1999. Augmentation of economic status of Bastar tribals through integrated (crop, livestock, poultry, duck, fish) farming system. Indian J Animal Sci. 69 (6): 448-52.

Varughese K, Mathew T. 2009. Integrated farming systems for sustainability in coastal ecosystem. Indian J Agron. 54(2): 120-127.

\section{How to cite this article:}

Anil Kumar Netam, Birbal Sahu and Chainu Ram Netam. 2019. Impacts of Integrated Farming System on Socio - economics and Livelihood Sustainability of Small and Marginal Farmers in Chhattisgarh. Int.J.Curr.Microbiol.App.Sci. 8(04): 822-829.

doi: https://doi.org/10.20546/ijcmas.2019.804.092 